\title{
MACRO- AND MICROMORPHOLOGY OF CENTAURIUM PULCHELLUM (Sw.) DRUCE GROWING IN EGYPT
}

\author{
M. A. El-Shanawany ${ }^{1}$, M. H. Mohamed ${ }^{2}$, A. A. Khalifa ${ }^{1}$ and M. A. Abd-Allah ${ }^{2}$ \\ ${ }^{1}$ Department of Pharmacognosy, Faculty of Pharmacy, Assiut University \\ ${ }^{2}$ Department of Pharmacognosy, Faculty of Pharmacy, Al-Azhar University

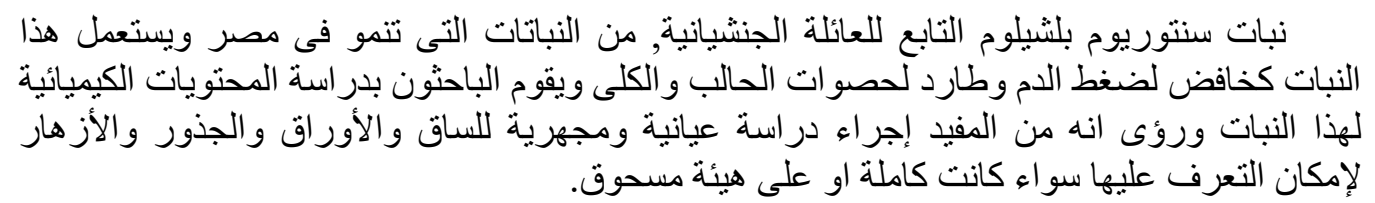

The detailed macro-and micromorphological characters of the stem, leaf, root and flower of Centaurium pulchellum ( $S w$.$) Druce growing in Egypt have been studied in order to find out$ the diagnostic features which can help in their identification in both entire and powdered forms.

\section{INTRODUCTION}

The genus Centaurium (Centaury) is a difficult genus with frequent hybridization and much parallel variation within their species. ${ }^{1}$ The genus Centaurium comprises about twelve species, they are annual or perennial herbs. ${ }^{2}$ The genus is often called Erythraea, which is derived from the Greek word erythro (red), from the pink colour of the flowers. ${ }^{3}$ Several species of the genus are native in Eastern North America. ${ }^{4,5}$

Centaurium pulchellum (Swartz) Druce (Syns. Erythraea ramosissima (Vill.) Pers, Erythraea pulchella (Sw.) Fries, Gentiana pulchella (Sw.) Gentiana ramosissima (Vill.) Pers, Slender centaury) is an erect littlebranched annual herb with all more or less stalked flowers, pink in colour, arranged at the ends of short branches, the main stem of which attaining a height of about (30-50) cm, belonging to family Gentianaceae. , $3,6-8^{-3}$

Crude drug obtained from some Centaurium species are mainly employed as stomachic, bitter tonic, to stimulate appetite, to relief dyspepsia, as antipyretic, treatment of hypertension, elimination of kidney and ureter stones, to relief renal, abdominal and gastric pain as well as healing agent for wounds in ointment of sciatica. ${ }^{9-21}$ In Arabic C. pulchellum is known as Qantariuon and Korteiba. ${ }^{7,22}$ In Egypt the plant is very common in the following regions: ${ }^{7}$
1- The Nile region including the Delta, the Valley and the Faiyum.

2- The Oases of Libyan desert, including Kurkur, Kharga, Dakhla, Farafra, Bahariya, Siwa and Wadi natrun.

3- The Mediterranean coastal strip from Elsallum to Rafah.

4- The Isthmic desert, i.e. El-Tih and the region north of Wadi Tumilat.

5- Sinai proper.

The phytochemical screening of the aerial parts of Centaurium pulchellum proved the presence of xanthones, secoiridoids, alkaloids, triterpenes, and phenolic acids. ${ }^{19,23}$ Reviewing the current literature, no further information could be traced concerning the macro- and micro morphology of the different organs of the plant. This work describes the macro-and micromor-phological characters as well as the powder of the stem, leaf, root and flower of Centaurium pulchellum (Sw.) Druce growing in Egypt.

\section{EXPERIMENTAL}

\section{Habitat}

Centaurium pulchellum (Sw.) Druce (Figs.1,2) is an erect little - branched annual herb with all more or less stalked, bell shaped flowers, pink in colour, arranged at the ends of short branches. ${ }^{2}$ The whole plant forming a lax leafy corymbosely cymose inflorescence and carries opposite 
decussate, exstipulate leaves and long capsular fruits containing numerous very small ovate seeds. ${ }^{2,7}$

\section{Plant material}

The plant material was collected from New Valley, $200 \mathrm{~km}$ south west of Assiut city, Egypt in May 2000, and was kindly identified by Prof. Dr. Salah El-nagar, Department of Botany, Faculty of Science, Assiut University. The collected fresh herbs were preserved in a mixture of alcohol (70\%) - glycerin - water (1:1:1) The different plant organs viz. stems, leaves, roots and flowers were separated airdried, reduced to fine powder and stored in a well-closed containers.

\section{1- The Stem}

\section{Macromorphology of the stem}

The main stem and the lateral branches of the plant (Figs. 1, 2) are erect, tetragonal in outline, hollow on drying, herbaceous, sympodially branched. The main stem reaches up to $30-50 \mathrm{~cm}$ in height and $0.1-0.2 \mathrm{~cm}$ in diameter. The internodes of the main stem and those of the lateral branches are variable in length varying from 2-4-7 cm. It is green in colour, with smooth surface and short fibrous fracture. It is odourless, and with very bitter taste.

\section{Micromorphology of the stem}

A transverse section in the stem (Figs. 3A, 3B) is tetragonal in outline with four prominent ridges. It shows an epidermis covered with thick cuticle, followed by a narrow cortex, a distinct endodermis, and one cell-wide parenchymatous pericycle surrounding the vascular tissue. The vascular tissue consists of a continuous ring of narrow outer phloem and wide inner xylem. Isolated strands of intraxylary phloem are observed at the periphery of the wide parenchymatous pith.

\section{The epidermis}

The epidermis (Figs. 4, 5A) consists of a single layer of large subrectangular cells covered with thick striated cuticle. In surface view (Fig. 5B) the cells are polygonal to subrectangular, axially elongated with more or less straight anticlinal walls, they measures 22-
64-170 $\mu$ in length, 14-20-24 $\mu$ in width and 5$11-21 \mu$ in height. Anisocytic of stomata are present.

\section{The cortex}

In the ridges, the cortex consists of usually one to two layers of irregularly shaped, thinwalled small chlorenchymatous cells, followed by comparatively large chlorenchymatous cells rounded to oval in shape. In between the ridges, the cortex consists of two to three cell-wide of rounded to oval chlorenchymatous cells with wide intercellular spaces. The endodermis is formed of one row of thin walled tangentially elongated cells devoid of starch granules (Figs. $4,5 \mathrm{~A})$.

\section{The pericycle}

The precycle is parenchymatous devoid of fibre and formed of one row of thin-walled cells (Figs. 4, 5A).

\section{The vascular system}

The phloem consists of shining thinwalled cellulosic soft elements of sieve tubes, companion cells and phloem parenchyma (Figs. $4,5 \mathrm{~A})$.

The xylem is a closed cylinder with no distinct medullary rays. It consists of a lignified comparatively wide zone of thick walled radially arranged elements. The xylary elements include vessels, fibres, tracheids, fibrous tracheids and wood parenchyma (Figs. $4,5 \mathrm{~A})$. The vessels, are arranged in radial rows, showing spiral and pitted thickenings, measuring 8-10-12 $\mu$ in diameter. The wood fibres, are abundant (Fig. 5B) each fibre is elongated showing narrow lumen, having straight lignified walls with fine oblique slitlike pits, acute apices and measuring about 320$365-410 \mu$ in length and 8-9-10 $\mu$ in diameter. Tracheids; having blunt ends and thick lignified pitted walls (Fig. 5B) and measuring 48-64-104 $\mu$ in length and 8-10-11 $\mu$ in diameter. Fibrous tracheids; having lignified walls with fine slitlike pits, wide lumen, acute to acuminate apices and measuring about 156-158-160 $\mu$ in length and 8-10-12 $\mu$ in diameter. The wood parenchyma (Fig. 5B) occurs usually in vertical rows, rectangular to subrectangular, with thin, pitted lignified walls, measuring $16-30-50 \mu$ in length and 10-12-16 $\mu$ in width. 


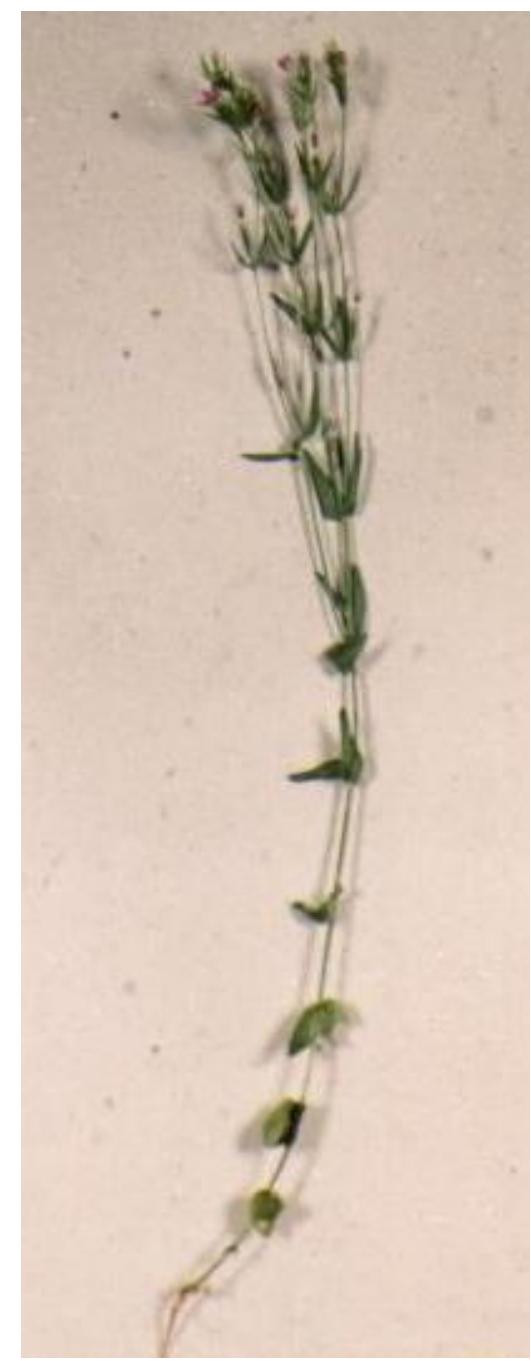

A

Fig. 1: A- Photo of the entire herb B- Photo of the aerial parts

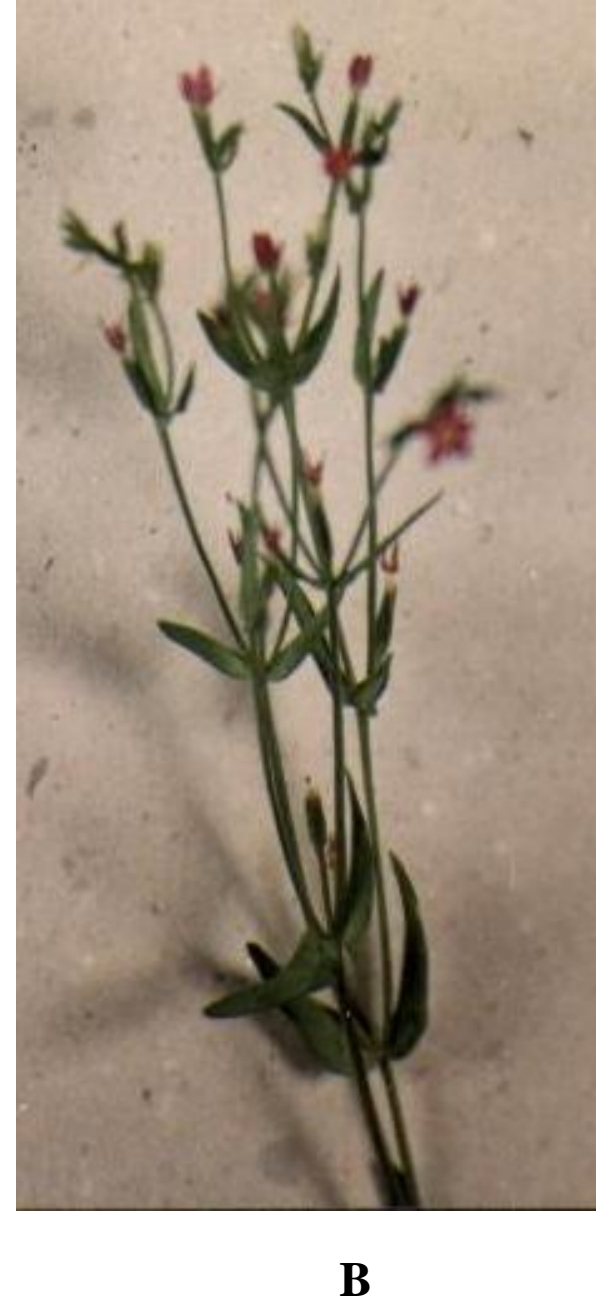

x 0.46

x 0.7 
Fig. 2: Sketch of the entire herb x 0.6

fl., flower, fr., fruit; 1. leaf; 1.r., lateral root; p.r., primary root; r., rootlet; st., stem. 


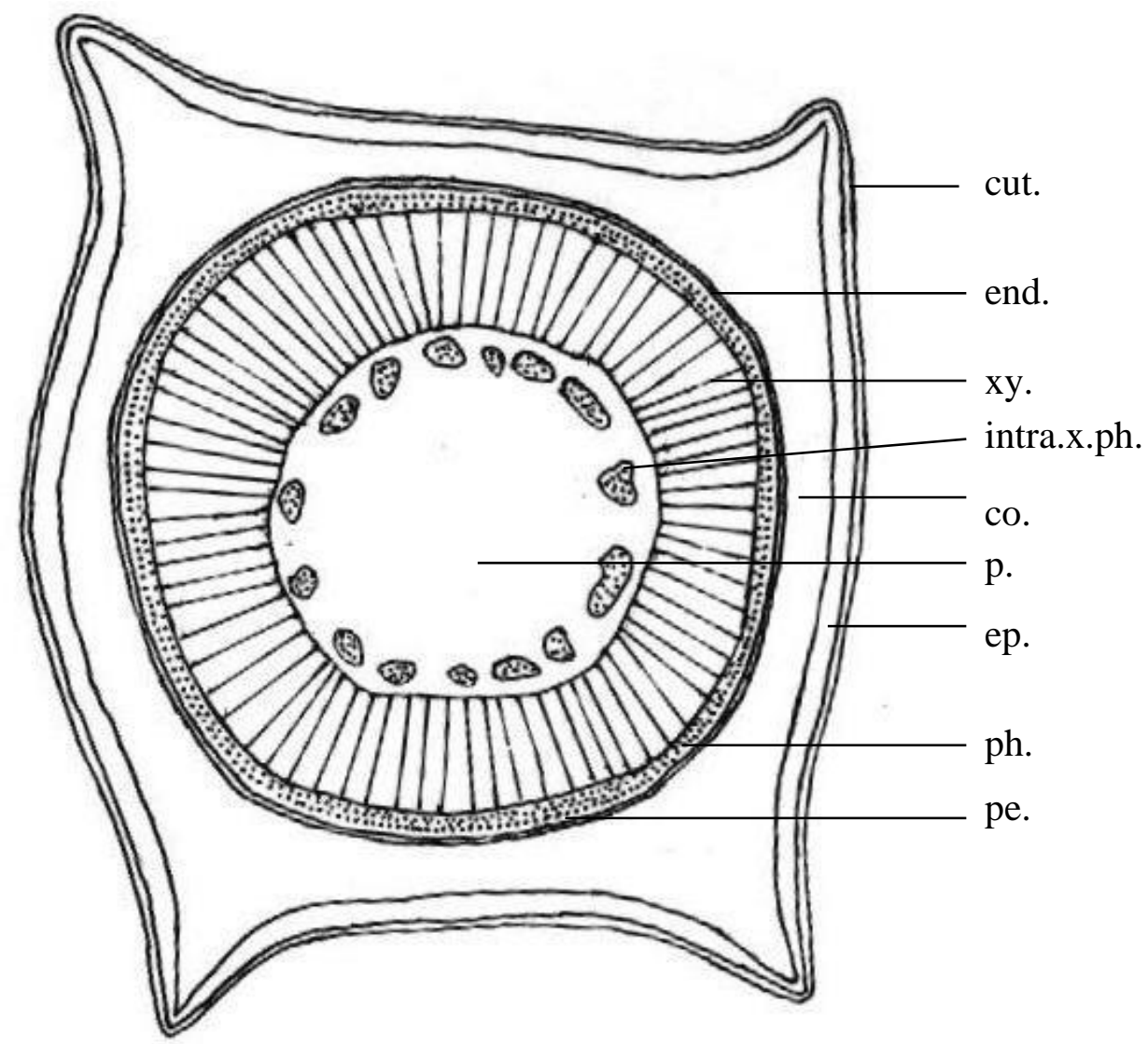

A

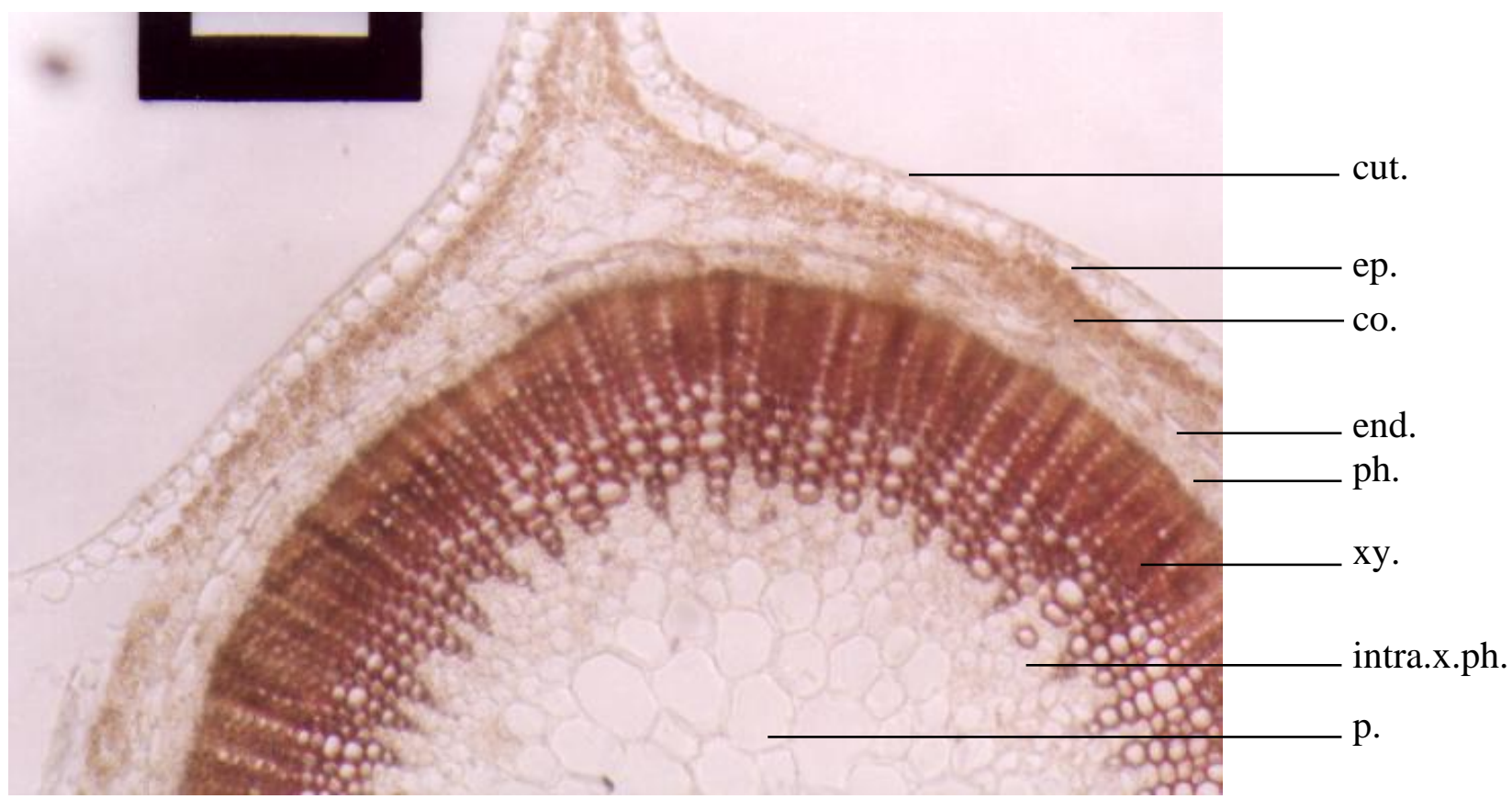

B

Fig. 3: A- Diagrammatic T.S. of the stem

$\mathrm{x} 130$

B- Photo of the diagrammatic T.S. of the stem

x 156

co., cortex; cut., cuticle; end., endodermis; ep., epidermis; intra.x.ph., intraxylary phloem; p., pith; pe., pericycle; ph., phloem; xy., xylem. 


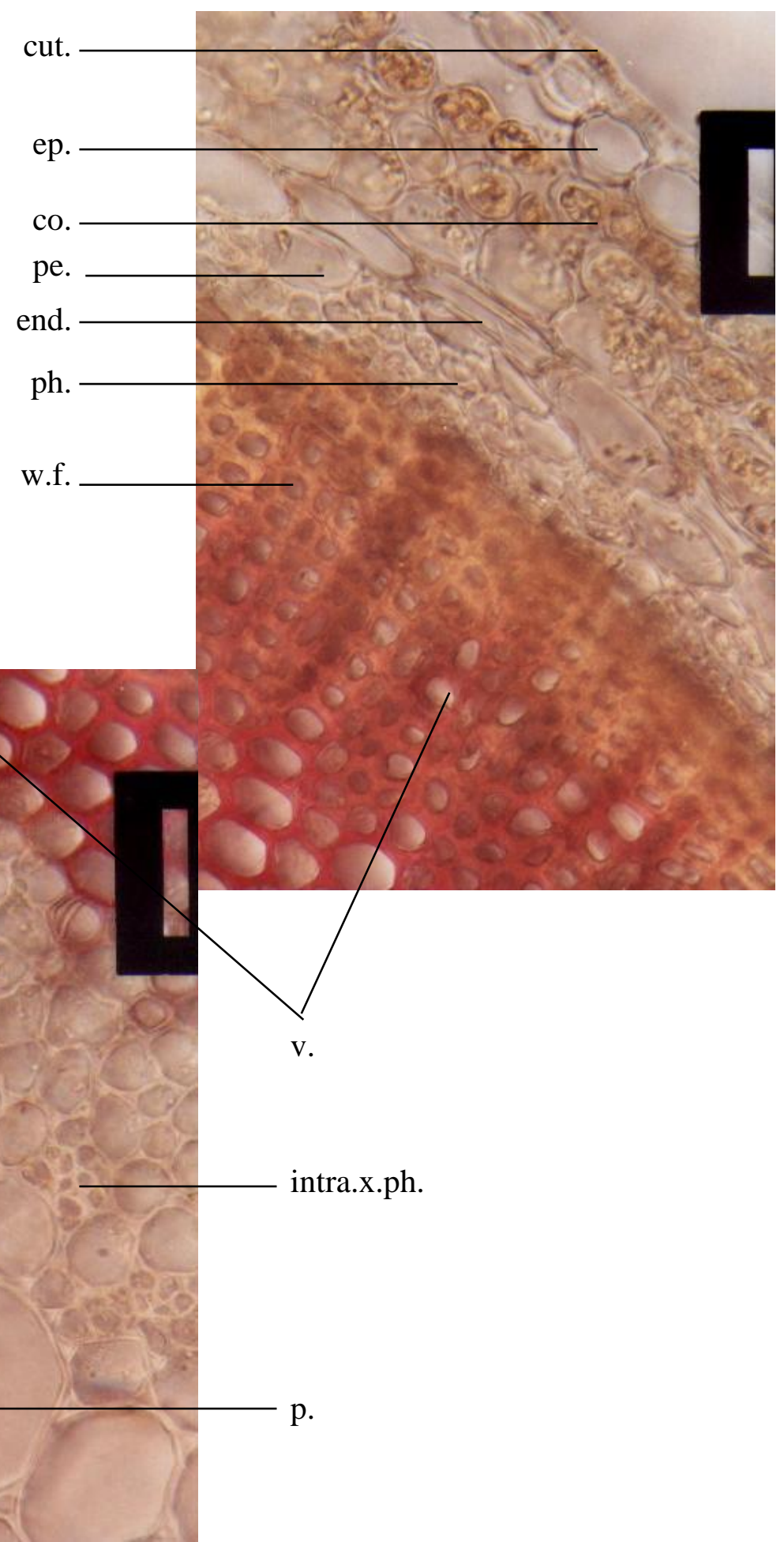

Fig. 4: Photo of detailed T.S. of the stem $\mathrm{x} 730$

co., cortex; cut., cuticle; end., endodermis; ep., epidermis; intra.x.ph., intraxylary phloem; p., pith; pe., pericycle; ph., phloem; v., vessel; w.f., wood fibre. 
Fig. 5: A- Detailed T.S. of the stem $\mathrm{x} 437.5$

B- Isolated elements of the stem

$\mathrm{x} 175$

(except xylem vessels and tracheids)

$\mathrm{x} 437.5$

co., cortex; cut., cuticle; end., endodermis; ep., epidermis; f.tr., fibrous tracheid; intra.x.ph., intraxylary phloem; p., pith; pe., pericycle; ph., phloem; tr., tracheid; w.f., wood fibre; xy.v., xylem vessel.

\section{The pith}

The pith (Figs. 4, 5A) is formed of an cells interrupted by strands of intraxylary phloem, and an inner zone of large rounded outer zone of small rounded parenchymatous 
thin-walled parenchymatous cells with no intercellular spaces.

\section{Anomalous structure}

Groups of intraxylary phloem elements are observed at the periphery of a wide pith (Figs. $4,5 \mathrm{~A})$.

\section{The powdered stem (Fig. 5B)}

The powdered stem is yellowish green in colour, odourless, with very bitter taste, it is characterized microscopically by the following features

1- Fragments of elongated epidermal cells, having straight anticlinal walls, covered with thick striated cuticle and showing anisocytic stomata.

2- Fragments of the vascular tissue consisting of lignified elements.

a) Pitted and spiral xylem vessels.

b) Tracheids, with lignified pitted walls.

C) Wood fibres, with acute apices and narrow lumen with fine pits.

d) Fibrous tracheids, with wide lumen, and acute to accuminate apices

e) Wood parenchyma.

\begin{abstract}
2-The Leaf

\section{Macromorphology of the leaf}

The leaves are opposite decussate exstipulate, simple and sessile (Figs. 2, $\left.8 \mathrm{~A}_{1}, \mathrm{~A}_{2}, \mathrm{~A}_{3}\right)$. They are ovate-lanceolate in shape with entire margin and symmetric bases. The apices of the upper and middle leaves are acute while those of the lower ones are blunt. The leaves have coraceous texture smooth glabrous surfaces and palmately reticulate venation. They are green in colour, odourless, with very bitter taste. The upper and lower leaves measure about 1.3-1.7 cm in length and 0.8-1 $\mathrm{cm}$ in width, while the middle one measures $1.8-2.5 \mathrm{~cm}$ in length and $1-1.4 \mathrm{~cm}$ in width.
\end{abstract}

\section{Micromorphology of the leaf}

A transverse section of the leaf (Fig. 6B, 8B) shows a midrib prominent on the lower surface. It shows centric mesophyll. ${ }^{24}$ The midrib region shows collateral vascular bundle.

\section{The upper epidermis}

The upper epidermis consists of a single layer of subrectangular, slightly irregular, thinwalled cells; some of them in the region of the lamina are slightly papillosed. In surface view (Figs. 6A $\mathrm{A}_{2}, \mathrm{~A}_{3}, 8 \mathrm{D}$ ) the cells are polygonal isodiametric or slightly elongated with sinuous anticlinal walls and covered with thick striated cuticle. They are measuring about 20-50-82 $\mu$ in length, $10-20-30 \mu$ in width and 12-16-20 $\mu$ in height. Anisocytic oval to rounded stomata are present and measure 10-12-15 $\mu$ in diameter.

The epidermal cells at the upper and lower neural region are similar (Figs. 6A $1,8 \mathrm{D}$ ). They are polygonal, axially elongated, rectangular cells with straight anticlinal walls and covered with thick striated cuticle. They are measuring about $40-60-100 \mu$ in length and $20-24-30 \mu$ in width and $16-18-22 \mu$ in height.

\section{The lower epidermis}

The lower epidermis (Figs. 6B, 7) consists of one layer of cells, which are similar to those of the upper epidermis but they are smaller in size. They measure 25-42-50 $\mu$ in length, 7-20$40 \mu$ in width and 13-15-21 $\mu$ in height. Anisocytic stomata are numerous.

\section{The mesophyll}

The mesophyll (Figs. 6B, 8C) is centric one, ${ }^{24}$ consists of only spongy tissue. The spongy tissue is formed of 4-6 rows of thinwalled rounded to slightly irregular chlorenchymatous cells with intercellular spaces.

\section{The Midrib}

The cortical tissue (Figs. 6B, 7) consists of cellulosic thin-walled, irregular parenchymatous cells with intercellular spaces.

\section{The vascular tissue}

Consists of a collateral vascular bundle formed of upper xylem and a lower narrow crescent shape phloem consisting of thinwalled soft cellulosic elements of sieve tubes, companion cells and phloem parenchyma. 

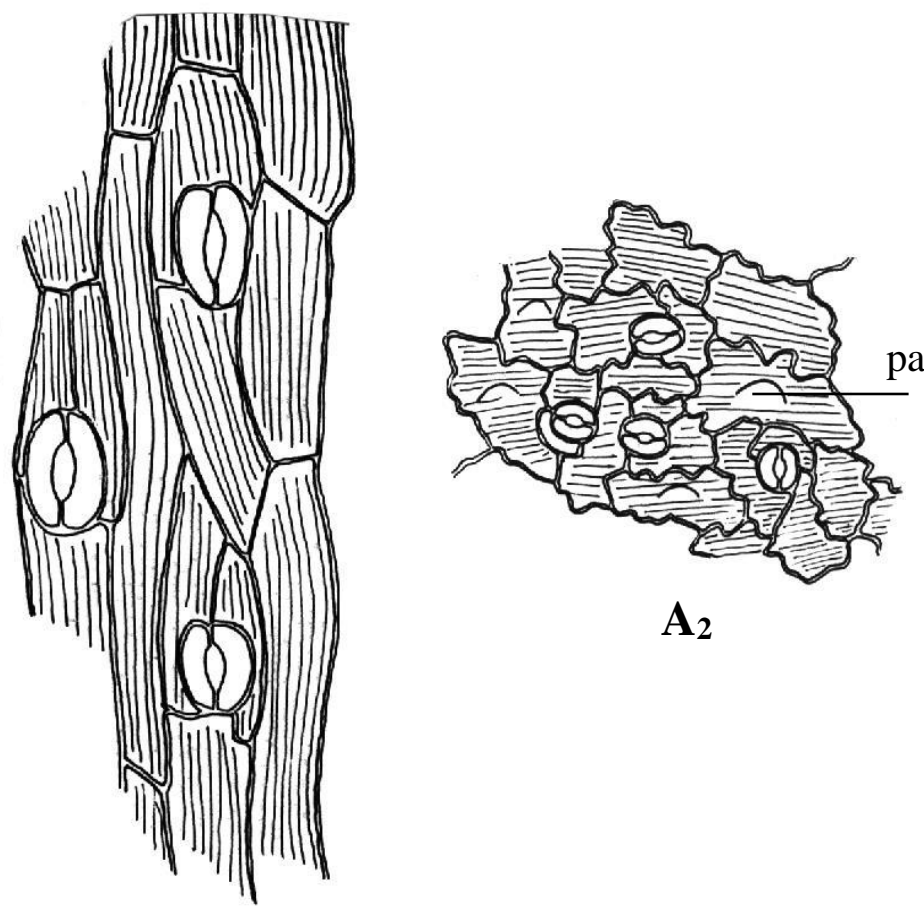

$\mathbf{A}_{2}$

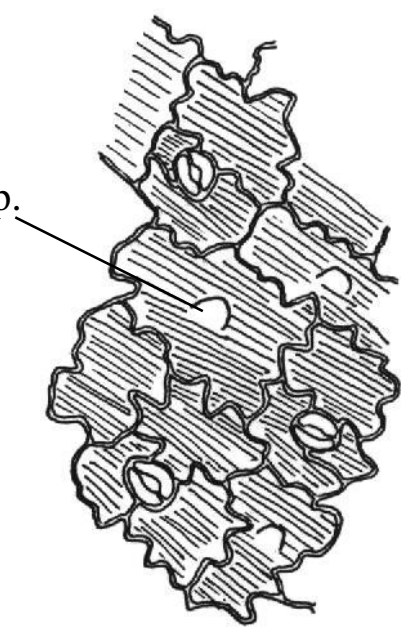

$\mathbf{A}_{3}$

A1

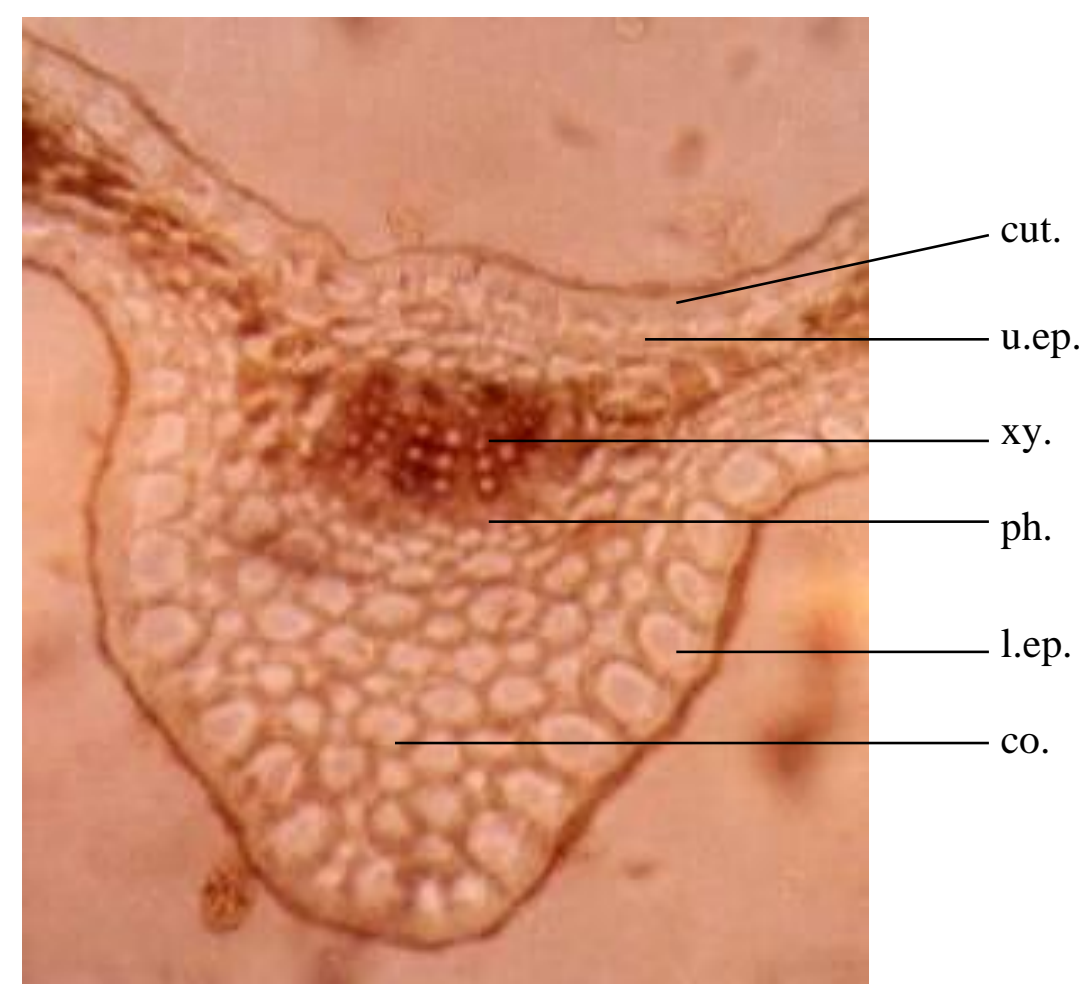

B

Fig. 6: A- Surface preparation of:

$\mathrm{A}_{1}=$ neural epidermis, $\mathrm{A}_{2}=$ lower epidermis, $\mathrm{A}_{3}=$ upper epidermis ) $\quad$ x 900

B- Photo of diagrammatic T.S. of the leaf x 300

co., cortex; cut., cuticle; l.ep., lower epidermis; pap., papillae; ph., phloem; u.ep., upper epidermis; xy., xylem. 
Fig. 7: Detailed T.S. of the midrib x 510

co., cortex; cut., cuticle; l.ep., lower epidermis; ph., phloem; u.ep., upper epidermis; xy., xylem. 
Fig. 8: A- Sketch of $A_{1}$-upper leaf, $A_{2}$ - middle leaf, $A_{3}$ - lower leaf

$\mathrm{x} 1.33$

B- Diagrammatic T.S. of the leaf

$\mathrm{x} 142.5$

C- Detailed T.S. of the lamina

$\mathrm{x} 415.6$

D- Isolated elements of the leaf

$\mathrm{x} 415.6$

co., cortex; cut., cuticle; l.ep., lower epidermis; n.ep., neural epidermis; pap., papillae; ph., phloem; sp.t., spongy tissue; u.ep., upper epidermis; xy., xylem; xy.v., xylem vessel.

The xylem (Fig. 7) is formed of lignified The vessels (Fig. 8D) are lignified with spiral radial rows of vessels and xylem parenchyma. and pitted thickenings measuring 5-7-9 $\mu$ in 
diameter. The xylem parenchyma is formed of polygonal elongated cells having thin cellulosic walls and measuring 6-8-12 $\mu$ in diameter.

\section{The powdered leaf}

The powdered leaf is green in colour, odourless, with very bitter taste. It is characterized microscopically by the following features: (Fig. 8D)

1- Fragments of the upper and lower epidermal cells, being polygonal, slightly elongated cells with sinuous anticlinal walls, covered with thick striated cuticle, some of them are shortly papillosed, and showing oval to rounded anisocytic stomata.

2- Fragments of neural epidermal cells showing polygonal, axially elongated cells with straight anticlinal walls, and covered with thick striated cuticle.

3- Fragments of lignified xylem vessels with spiral and pitted thickenings.

\section{3-The Root}

\section{Macromorphology of root}

The root consists of short cylindrical, fusiform, tap root 7-13 cm long and about 0.08$0.1 \mathrm{~cm}$ in diameter at the middle part and numerous, spreading long lateral roots, leaving the main root at nearly right angles. The lateral roots bear in turn numerous rootlets (Fig.9D). Externally the root is reddish - yellow in colour with rough surface. It is odourless, but possesses a very bitter taste.

\section{Micromorphology of the root}

A transverse section of the root (Fig. 9A) is nearly circular in outline showing an outer exodermis, followed by a collapsed cortex, the endodermal zone and parenchymatous pericycle. The vascular tissues show an outer narrow primary and secondary phloem, one layer of cambium and wide primary and secondary xylem. The center of the root shows an interxylary phloem as anomalous structure. The primary xylem is diarch.

\section{The exodermis}

The exodermis (Fig. 9B) consists of few layers of slightly rectangular irregular cells containing brown pigments. In surface view (Fig. 9C) the exodermal cells are rectangular axially elongated with straight to slightly wavy anticlinal walls. They measure about 18-24-31 $\mu$ in length, 8-12-16 $\mu$ in width and 11-12-14 $\mu$ in height.

\section{The cortex (Fig. 9B)}

The cortex consists of few layers of collapsed parenchymatous cells. the endodermis appears in three to four layers by tangential division (Figs. 9B, 10A) forming endodermal zone. The first layer of which was divided radially. ${ }^{25}$

\section{The pericycle}

The pericycle (Figs. 9B, 10A) consists of one to two layers of parenchymatous cells.

\section{The vascular tissue The phloem}

It consists of thin-walled shining cellulosic elements composed of sieves tubes, companion cells and phloem parenchyma, devoid of any fibers (Figs. 9B,10A).

\section{The cambium}

The cambium (Fig.9B) consists of one layer of cambiform cells, which are subrectangular, and tangentially elongated.

\section{The xylem}

It consists of wide zone of lignified thickwalled radially arranged elements (Fig. 9B).The xylem elements include vessels, fibres, tracheids and fibrous tracheids (Fig. 9C).The vessels, are arranged in radial rows, showing pitted and spiral thickening measuring about 910-14 $\mu$ in diameter. The tracheids (Fig. 9C), have lignified pitted walls, wide lumen and measuring about $112 \mu$ in length and $12 \mu$ in diameter. The wood fibres, are abundant, having straight to slightly curved outline, narrow lumen, lignified walls with fine pits, acute to acuminate apices and measuring about 256-288-298 $\mu$ in length and 8-10-12 $\mu$ in diameter. Fibrous tracheids, having straight to slightly irregular lignified walls, comparatively wide lumen with fine pits, acute apices, more or less curved at one end and measuring about 280-290-300 $\mu$ in length and 10-12-14 $\mu$ in diameter. 
Fig. 9: A- Diagrammatic T.S. of the rootx 43

B- Detailed T.S. fo the root

$\mathrm{x} 415.6$

C- Isolated elements of the root

$\mathrm{x} 415.6$

D- Sketch of the root

$\mathrm{x} 1.42$

camb., cambium; co., cortex; end., endodermis; ex., exodermis; f.tr., fibrous tracheid; inter.x.ph., interxylary phloem; 1.r., lateral root; pe., pericycle; ph., phloem; p.r., primary root; r., rootlet; tr., tracheids; v., vessel; w.f., wood fibre; xy., xylem. 


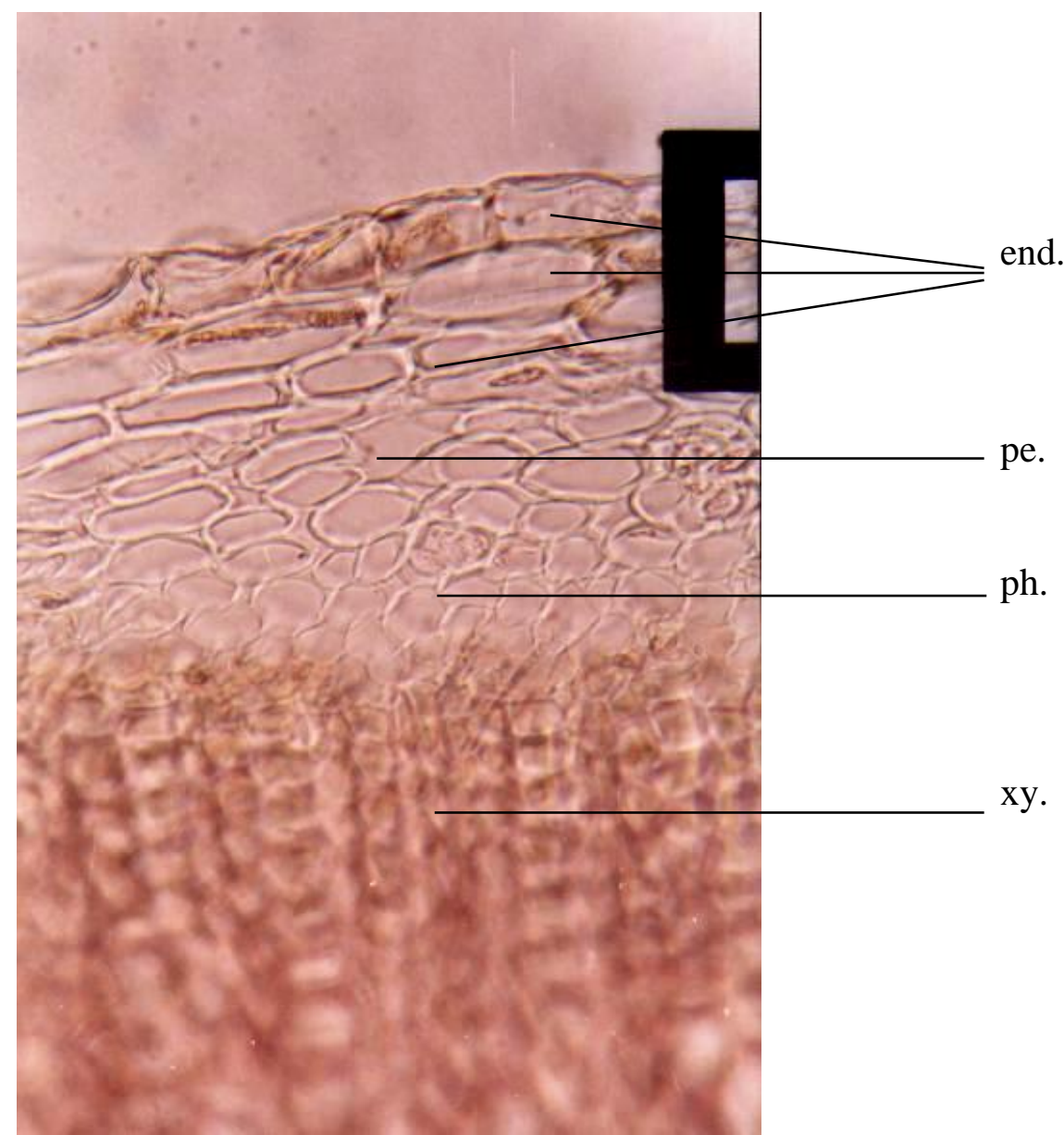

A

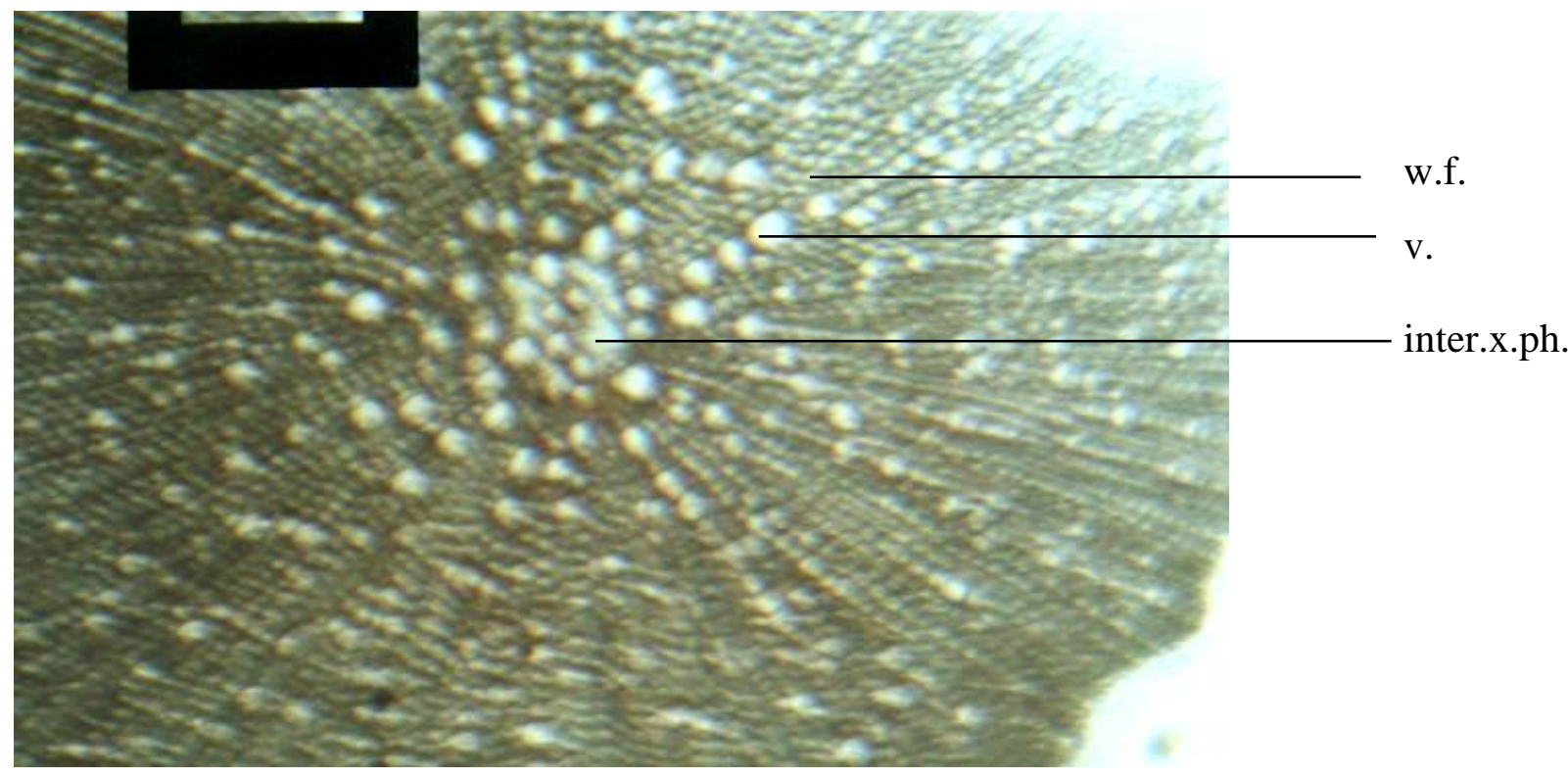

B

Fig. 10: A- Photo of detailed T.S. of the root with exfoliated primary cortex and exodermis

B- Photo of diagrammatic T.S. of the root (xylary region)

end., endodermis; inter.x.ph., interxylary phloem; pe., pericycle; ph., phloem; xy., xylem. 


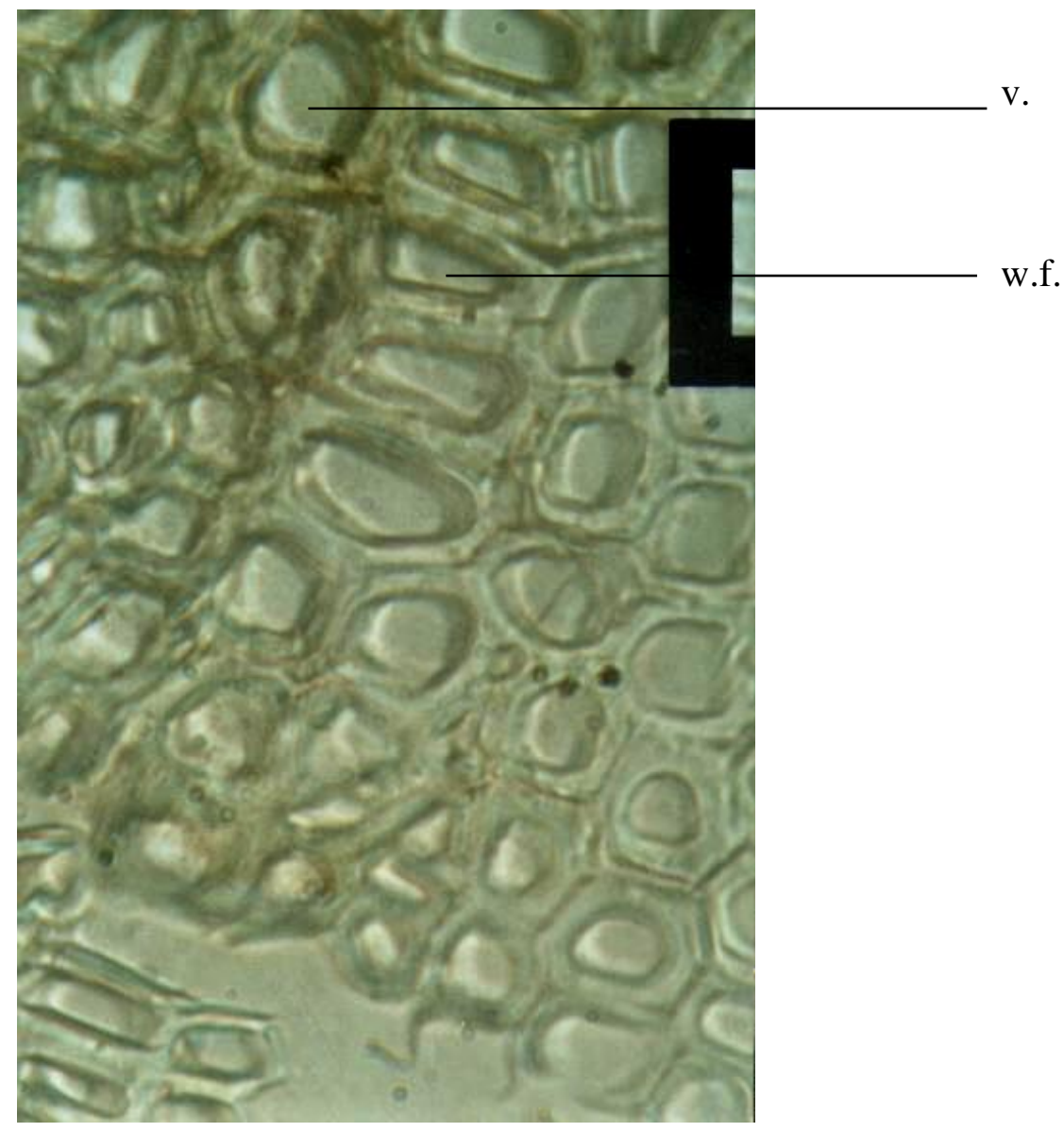

$\mathbf{A}$

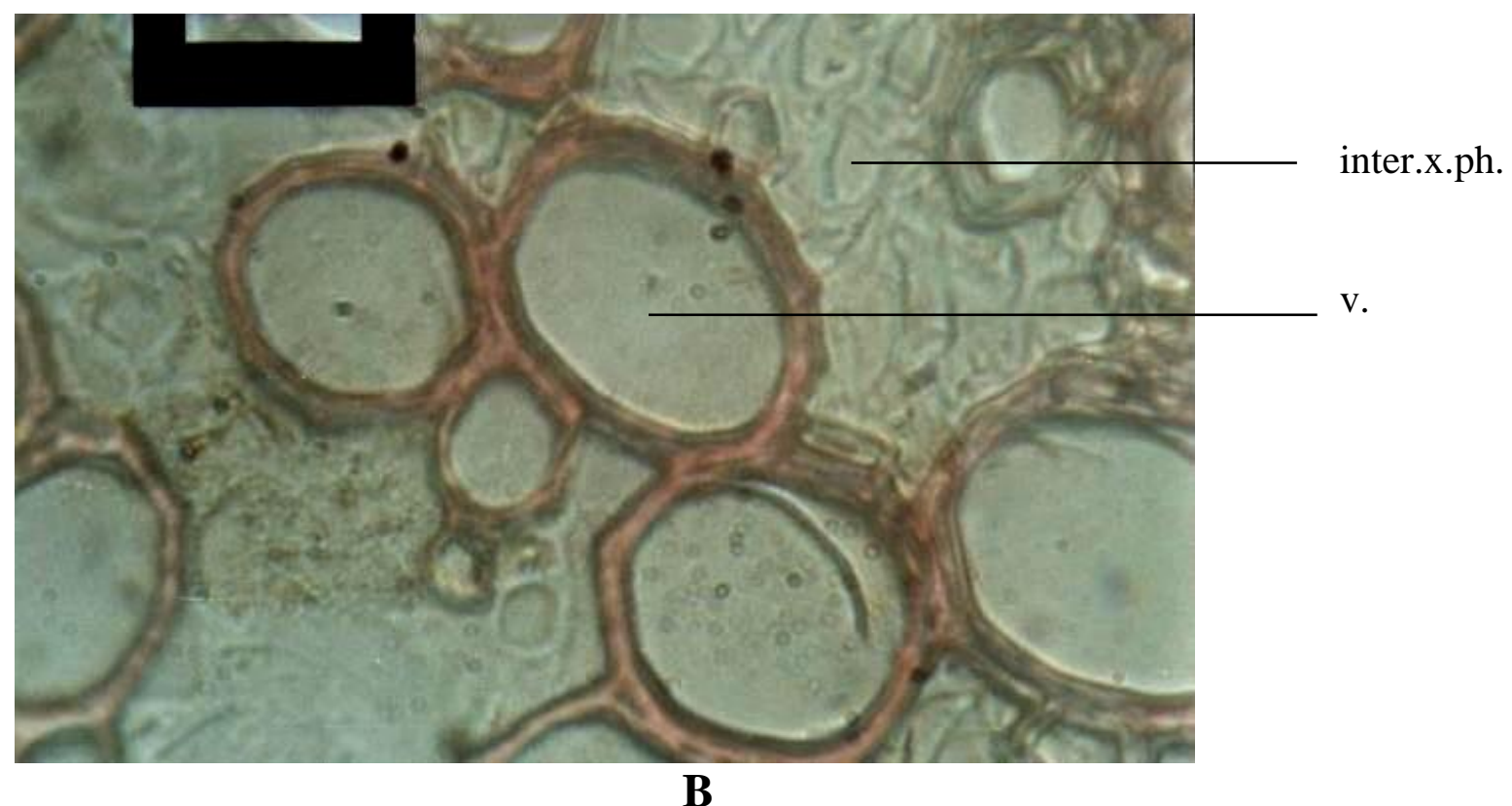

Fig. 11: A- Photo of detailed T.S. of the root

(xylary region)

x 1095

B- Photo of detailed T.S. of the root

(interxylary phloem)

x 1095

inter.x.ph., interxylary phloem; w.f., wood fibre; v., vessel. 


\section{Anomalous structure}

Interxylary phloem in the form of group of phloem elements interrupted by isolated xylem vessels occupies the center of the root (Figs. 9B, 10B, 11B).

\section{The powdered root (Fig. 9C)}

The powdered root is yellowish white in colour, odourless, with very bitter taste, showing the following features.

1- Fragments of the exodermis, showing rectangular thin - walled cells, with slightly wavy anticlinal walls and, and containing brown pigments.

2- Fragments of lignified xylem elements, consists of:

a) Pitted and spiral xylem vessels.

b) Fibres with wide lumen and acute apices.

c) Tracheids with lignified walls and pitted thickenings.

d) Fibrous tracheids, with wide lumen, lignified walls and curved at one end.

\section{4- The Flower}

\section{Macromorphology of the flower (Fig. 12C)}

It is pedicellate, pink in colour, arranged at the ends of short branches and the whole plant forming a lax leafy corymbosely cymose inflorescence. The flower is actinomorphic, hermaphrodite, tetracyclic, pentamerous and epigenous. Each flower measuring about 1.3$1.6 \mathrm{~cm}$ long and $0.3-0.5 \mathrm{~cm}$ wide.

\section{The pedicle}

Is irregularly winged, tetragonal in outline, externally smooth, green in colour and measuring $0.2-0.7 \mathrm{~cm}$ long and $0.05-0.07 \mathrm{~cm}$ in diameter.

\section{The calyx}

Is symsepalous, tubular consists of five united to about one third their length, keeled sepals forming a tube with five teethed acute apices. Each sepal is linear with thick, dark green central midrib and membranous lamina with entire margin. The sepal measure 0.7-1.2 $\mathrm{cm}$ in length and $0.15-0.2 \mathrm{~cm}$ in width.

\section{The corolla}

Is membranous, bright pink in colour, sympetalous, consists of five united petals forming a bell with five diverging apical teeth, measuring 0.4-0.7 $\mathrm{cm}$ long and 0.3-0.5 cm wide. Each petal is ovate in shape with obtuse apex and entire margin. It has smooth surface and palmately reticulate venation.

\section{The androecium}

The androecium consists of five epipetalous stamens with equal filaments. Each stamen has wiry filament attaining about 0.2$0.3 \mathrm{~cm}$ in length, and carrying pale yellowishwhite bilobed, basifixed, entrorse anthers. Each anther lobe measures $0.15-0.2 \mathrm{~cm}$ in length. Each anther lobe possesses two elongated pollen sacs which containing numerous pollen grains.

\section{The Gynaecium}

Is formed of yellowish-green ovary short style and bilobed stigma. The ovary is long, superior, bicarpellary, unilocular and show numerous ovules arranged in parietal placenta. It attains $0.1-0.2 \mathrm{~cm}$ in diameter. The style is cylindrical, bearing bilobed stigma. It attains $0.5-0.6 \mathrm{~cm}$ long and $0.05-0.06 \mathrm{~cm}$ in diameter.

\section{Micromorphology of the flower The pedicel}

A transverse section through the pedicel (Fig. 12A) shows an irregular outline with four unequal wings and wavy sides. It shows a single layer of epidermal cells surrounding a chlorenchymatous cortex, a distinct endodermis. One cell wide parenchymatous pericycle surrounding the vascular system. The vascular system is formed of few phloem elements, parenchymatous xylem and few xylem vessels. Patches of intraxylary phloem are present at the periphery of central pith.

\section{The epidermis}

The epidermis (Fig.12B) consists of a single layer of subrectangular cells covered with thick striated cuticle. In surface view (Fig. $14 \mathrm{H})$ the cells are polygonal to subrectangular, axially elongated with more or less straight anticlinal walls. They measure $16-60-92 \mu$ in length and 7-10-13 $\mu$ in width and 8-9-10 $\mu$ in height. Anisocytic type of stomata is present.

The cortex (Figs. 12B, 13A)

Consists of thin-walled chlorenchymatous cells rounded to oval in shape. 
Fig. 12: A- Diagrammatic T.S. of the flower pedicel $x 176$

B- Detailed T.S. of the flower pedicel $\quad \times 762$

C- Sketch of the flower, the corolla laid open $\mathrm{x} 16$

an., anther; cal., calyx; co., cortex; cor., corolla; cut., cuticle; end., endodermis; ep., epidermis; fil, filament; f.st. flower stalk; intra.x.ph., intraxylary phloem; ov., ovary; p., pith; pe., pericycle; ph., phloem; sti., stimga; sty., style; v., vessel. 

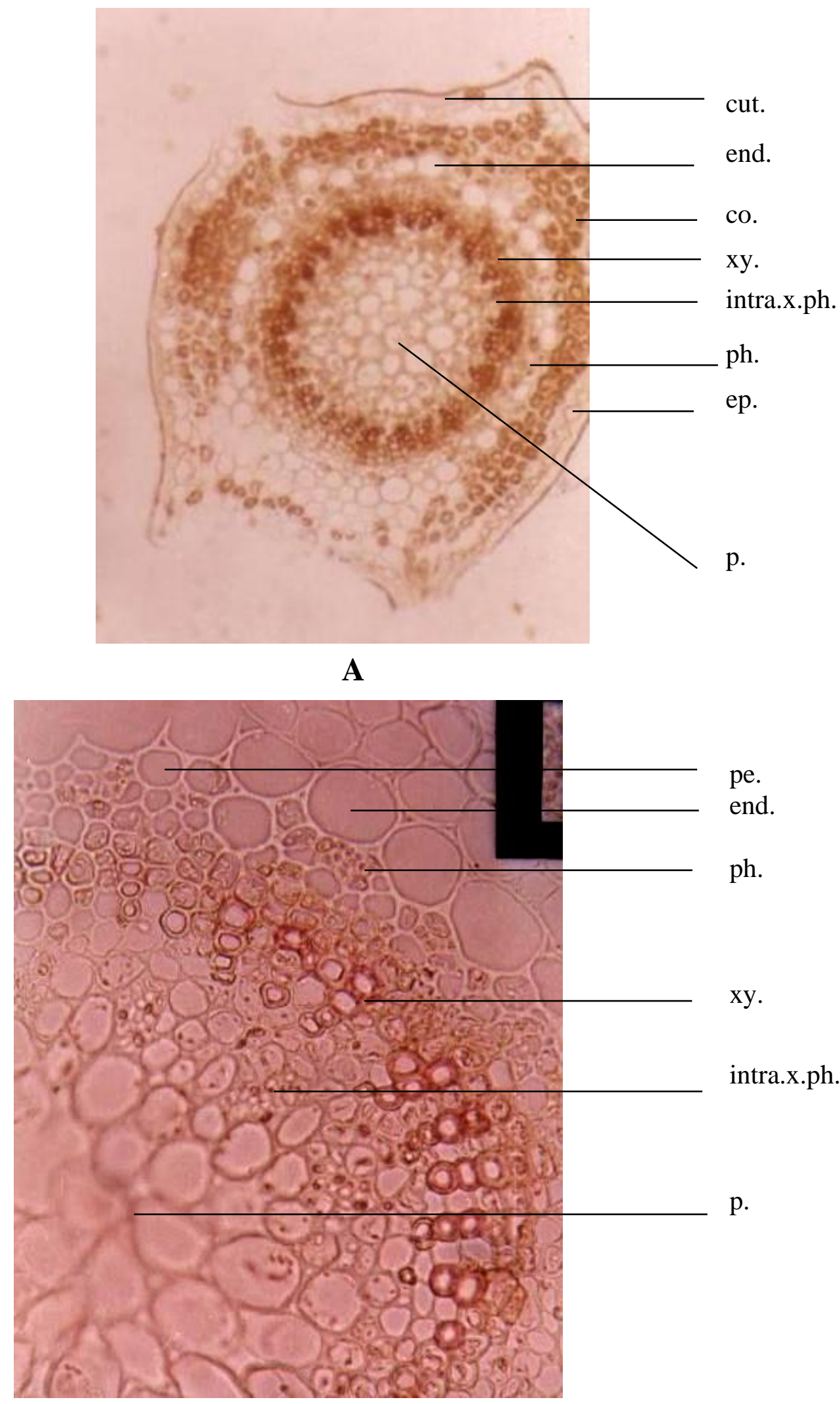

B

Fig. 13: A- Photo of diagrammatic T.S. of the flower pedicel

x 113.75

B- Photo of detailed T.S. of the flower pedicel (vascular tissue and pith)

$\mathrm{x} 1137.5$

co., cortex; cut., cuticle, end., endodermis; ep., epidermis; intra.x.ph., intraxylary phloem; p., pith; ph., phloem; xy., xylem. 
Fig. 14: Isolated elements of the flower

A- Surface preparation of the epidermis of the calyx (upper and lower surfaces are similar)
$\mathrm{A}_{1}$ - Epidermal cells at apical region
$\mathrm{x} 437.5$

$\mathrm{A}_{2}$ - Epidermal cells of middle and basal region

B- Surface preparation of the epidermis of the corolla

$\mathrm{B}_{1}$ - Epidermal cells at apical region

$\mathrm{x} 437.5$

$\mathrm{B}_{2}$ - Epidermal cells of middle and basal region

$\mathrm{x} 437.5$

C- Pollen grains

$\mathrm{x} 437.5$

D- Papillosed epidermis of the stigma

$\mathrm{x} 437.5$

E- Surface view of the epidermis of the style

$\mathrm{x} 437.5$

$F_{1}$ - Surface view of the fibrous layer of the anther

$\mathrm{x} 437.5$

$\mathrm{F}_{2}$ - Side view of the fibrous layer of the anther

$\mathrm{x} 437.5$

G- Xylem vessel of the flower pedicel

$\mathrm{x} 437.5$

$\mathrm{H}$ - Surface view of the epidermis of the flower pedicel

$\mathrm{x} 437.5$

I- Surface view of the epidermis of the filament

$\mathrm{x} 437.5$

The endodermis (Figs. 12B, 13A, 13B)

Consists of one layer of rectangular thinwalled cells devoid of starch granules. 


\section{The pericycle (Fig. 12B)}

Consists of one cell wide parenchymatous cells.

\section{The vascular system \\ The phloem (Figs. 12B, 13B)}

Consists of shining thin-walled, cellulosic, soft elements of sieve tube companion cells and phloem parenchyma.

\section{The xylem (Figs. 12B, 13B)}

Consists of comparatively wide zone of xylem parenchyma, few thick-walled lignified xylem vessels. The vessels show spiral thickening and measure 4-6-9 $\mu$ in diameter.

\section{The pith}

Is formed of thin-walled parenchymatous cells with intercellular spaces.

\section{Anomalous structures (Figs.12B, 13B)}

Isolated strands of intraxylary phloem appear at the periphery of the pith.

\section{The calyx (Figs. 14A $1, A_{2}$ )}

The upper and lower epidermises of the sepals show polygonal axially elongated cells, with sinuous anticlinal walls and covered with thin striated cuticle. The apical cells in both surfaces are small than the middle and basal cells and measuring about $12-40-52 \mu$ in length and 8-13-26 $\mu$ in width, the middle and basal cells measure about 20-88-105 $\mu$ in length and 8-13-26 $\mu$ in width. Both upper and lower epidermises show anisocytic type of stomata.

\section{The corolla (Figs. 14B $1, B_{2}$ )}

The upper and lower epidermises of the petal are polygonal in outline, with thin cellulosic, wavy anticlinal walls and covered with thin smooth cuticle. The apical cells of both surfaces are smaller than the middle and basal cells and measuring about 20-36-50 $\mu$ in length and 5-9-16 $\mu$ in width. The middle and basal cells are the same size and measuring about 44-51-68 $\mu$ in length and 6-8-9 $\mu$ in width.

\section{The androecium}

The epidermis of the filament (Fig. $14 \mathrm{I}$ ) is formed of polygonal cells with thin cellulosic straight anticlinal walls and covered with faintly striated cuticle. They are measuring about $30-35-37 \mu$ in length and 4-5-6 $\mu$ in width. The Epidermis of the Anther is formed of polygonal to isodiametric cells with thick lignified beaded anticlinal walls with rod-like thickenings. They are measuring about 13$14-16 \mu$ in length and $12-13-14 \mu$ in width and 5-6-7 $\mu$ in height (Fig. 14F)

\section{The pollen grains}

Are spherical in shape with four germinal pores and smooth exine. Each of them attains about $8 \mu$ in diameter (Fig. 14C)

\section{The gynaecium}

The epidermal cells of the style (Fig. 14E) are polygonal in outline, with straight anticlinal walls and covered with faintly striated cuticle, they are measuring about $19-20-21 \mu$ in length and 4-5-6 $\mu$ in width. The style bears numerous club shaped papillae measuring about 32-54-75 $\mu$ long and 14-16-19 $\mu$ wide.

\section{The powdered flower (Fig. 14)}

The powdered flower is yellowish-green in colour with some pink fragments of the corolla, odourless, and has a very bitter taste. It is characterized microscopically by the following features.

1- Fragments of the epidermal cells of the pedicel with polygonal to subrectangular straight-anticlinal walled, axially elongated covered with thick striated cuticle and showing rounded anisocytic stomata.

2- Fragments of the upper and lower epidermal cells of the sepals show polygonal axially elongated cells, with thin sinuous anticlinal walls and covered with thin striated cuticle and showing rounded anisocytic stomata.

3- Fragments of the epidermal cells of the petals showing polygonal thin wavyanticlinal walled cells, covered with thin smooth cuticle.

4- Fragments of the fibrous layer of the anther showing polygonal lignified cells with barlike thickenings, which appear as beads in surface view.

5- Fragments of the epidermal cells of the style showing polygonal cells with thin straight anticlinal walls and covered with faintly striated cuticle.

6- Fragments of the stigmatic surface showing club-shaped papillae protruding from the cells of the epidermis. 
7- Numerous pollen grains with four germinal pores and smooth exine.

8- Fragments of the epidermal cells of the filament showing polygonal thin straightwalled cells covered with faintly striated cuticle.

9- Fragments of the spiral lignified xylem vessel of the flower pedicel.

\section{REFERENCES}

1- G. Bentham and J. D. Hooker, "Flowers of South-West Europe", London Oxford University Press, New York, Toronto, 1973, p. 295.

2- B. Everard, "Flowers of Europe", London Oxford University Press, New York, Toronto, 1969, pp. 313-314.

3- M. M. Grieve, "A Modern Herbal", Dover Publication, INC., New York Vol. 1, 1983, p. 183.

4- R.Muschler, "A Manual Flora of Egypt", S-H Servica Agency, INC., New York, N.Y., 1970, pp. 331-333.

5- W. G. Van der Sluis, "Plant Systematic Evaluation", 1985, pp. 253-286.

6- A. M. Migahid and M. A. Hammouda, "Flora of Saudia Arabia", Riyad University Publication, 1974, p. 219.

7- V.Tackholm,"Student's Flora of Egypt", Cairo University Press, Cairo, Egypt, $2^{\text {nd }}$ Edn., 1970, pp. 21-23.

8- S. Ary and M. Gregory, "The Oxford Book of Wild Flowers, Pocket Edition", Oxford University Press, Oxford, New York, Toronto, Melborne, 1970, pp. 70-71.

9- C. W. Fetrow and J. R. Avila, "The Complete Guide to Herbal Medicines", Springhouse Corporation Springhouse, 1999, pp. 120-121.

10- H. Fluck, "Medicinal Plants and Their Uses", London W. Foulsham Co. LTD, New York Toronto, Cape Town Sydney, 1973, p. 119.

11- C. A. Newall, L.A. Anderson and J.D. Phillipson, "Herbal Medicines", The Pharmaceutical London Press, 1996, p. 67.

12- J. Barnes. L. A. Anderson and J. D. Phillipson, "Herbal Medicines", London, Chicago Pharmaceutical Press, 2002, pp. 121-123.

13- H. W. Griffith, "Healing Herbs", University of Arizona, Prevention Center, 2000, pp. 73-74.
14- S. Mills and K. Bone, "Principles and Practice of Phytotherapy", Edinburgh, London, New York, Philadelphia, St. louis, Sydney, Toronto, 2000, pp. 38-41.

15- R. F. Weiss and V. Fintelmann, "Herbal Medicine", Thiema Stuttgart, New York, $2^{\text {nd }}$ Edn., pp. 2000, 52-53.

16- K. Keville, "Herbs For Health and Healing", INC. Emmaus, Pennsylvania, Rodale Press, 1996, pp. 91-92.

17- O. Schimmer and H. Mauthner, Planta Medica, 62, 561-64 (1996).

18- M. Parra, M. T. Picher, E. Seoane and A.Tortajada, J. of Natural Product, 47 (1), 123-26 (1984).

19- M. A. El-shanawany, M. A. Makboul and A. M. Abdel Baky, Bull Pharm. Sci., Assiut University, 12 (3), 416-21 (1989).

20- H. F. Farrag and M. A. Sheriff, J. Pharm. Pharmacol., 1, 219, (1949).

21- A. M. Rizk and G. A. El-Ghazaly, "Medicinal and Poisonous Plants of Qatar", University of Qatar, Doha (1995).

22- K. H. Batanouny, "Wild Medicinal Plants in Egypt", Plam Press, 34, Al-Mansour Mohammed Street, Zamalek, Cairo 11211, Egypt.

23- A. M. Rizk and G. A. El-Ghazaly, "The Phytotherapy of The Flora of Qatar", Scientific and Applied Research Center, University of Qatar, 1986, pp. 145-147.

24- T.E. Wallis, "Textbook of Pharmacognosy", CBS Publisher and Distributors, J. Bhawan, B.N., Nagar, S.Delhi-11032 India, ${ }^{\text {th }}$., Edn., 1973, p. 114.

25- C.R. Metcalfe and L. Chalk, "Anatomy of The Dicotyledons", Vol. 2, Oxford at The Claredon Press, 1972, pp. 933-939. 